\title{
Telomerase Cajal Body Protein 1
}

National Cancer Institute

\section{Source}

National Cancer Institute. Telomerase Cajal Body Protein 1. NCI Thesaurus. Code C102961.

Telomerase Cajal body protein 1 ( $548 \mathrm{aa}, \sim 59 \mathrm{kDa}$ ) is encoded by the human WRAP53 gene. This protein is involved in the positive regulation of telomere synthesis. 